\title{
Potential impact of winter temperature increases on South Carolina peach production
}

\author{
Gregory J. Carbone ${ }^{1}$, Mark D. Schwartz ${ }^{2}$ \\ ${ }^{1}$ Department of Geography, University of South Carolina, Columbia, South Carolina 29208, USA \\ ${ }^{2}$ Department of Geography, University of Wisconsin-Milwaukee, Milwaukee, Wisconsin 53201, USA
}

\begin{abstract}
Two scenarios of climatic change were examined to determine the potential impact of winter-season warming on peach production in South Carolina, USA. The daily maximum and minimum temperatures from 1961 to 1990 were increased by $2^{\circ} \mathrm{C}$ and $4{ }^{\circ} \mathrm{C}$ at 26 stations to simulate how increased winter temperatures could affect chilling during the dormant season and the last spring frost date. An average winter temperature increase of $2^{\circ} \mathrm{C}$ would decrease chilling hour accumulation by approximately $400 \mathrm{~h}$ and approach the minimum required chlling hours of most peach varieties currently grown in the state. A $4{ }^{\circ} \mathrm{C}$ warming would result in average chilling hour accumulation ranging from $775 \mathrm{~h}$ in coastal regions, to $1350 \mathrm{~h}$ in the Piedmont. If growers continued to use current peach varieties, such warming would substantially decrease the probability of achieving sufficient chilling hours during the dormant season. However, the scenarios of winter temperature increases must also be viewed with regard to the hazards of spring frost. Our analysis shows that the date of the mean spring frost could occur approximately 2 and 4 wk earlier than at present for $2^{\circ} \mathrm{C}$ and $4{ }^{\circ} \mathrm{C}$ winter warming scenarios, respectively. Future work assessing the vulnerability of peaches to climatic change will require greater insight into the expression of climatic change, the relationship between environmental variables and peach phenology, and the adjustment strategies that growers could use to adapt to certain changes.
\end{abstract}

\section{INTRODUCTION}

Results from general circulation models (GCMs) have shown that projected increases in atmospheric greenhouse gas concentrations could cause substantial changes in the earth's climate (Manabe \& Wetherald 1987, Wilson \& Mitchell 1987. Hansen \& Lebedeff 1988, Hansen et al. 1988, Washington \& Meehl 1989). While some controversy exists over how much temperature and precipitation patterns would be altered and how such changes would be expressed (Katz 1988, Lindzen 1990), projected climatic changes are significantly large to warrant concern over their potential impacts (Smith \& Tirpak 1989, Jäger \& Ferguson 1991, National Academy of Sciences 1991).

This concern has prompted impact studies relating climatic change to sea level rise (Eid \& Hulsbergen 1991), marine resources (Beukema et al. 1990), water resources (Waggoner 1990), and agriculture (Parry \& Carter 1985, Peart et al. 1989, Ritchie et al. 1989, Adams et al. 1990, Cooter 1990, Rosenzweig 1990), among other topics. Agricultural impact studies have shown that potential climatic changes could alter crop yields, cause a shift in the location of broad agricultural regions, or lead to changes in agricultural practices. Because of their importance to world food supplies, major grain crops (such as wheat, maize, and soybeans) have been the focus of most agricultural impact studies. Clearly, climatic variability and change could affect other crops both positively and negatively, and could lead to impacts on regional economies.

This study examines how climatic change could influence peach production in South Carolina, USA. We examine the sensitivity of the peach crop to recent climatic change projections for the southeastern United States in order to measure how average winter temperature increases would threaten the important winter chilling period for peach trees, yet simultaneously mitigate the threat of freeze damage to the peach crop. In addition, we examine how adaptation to current inter-annual variability could buffer the impact of climatic change. 


\section{PEACHES AND CLIMATIC HAZARDS}

Peach trees require a period of winter dormancy, or chilling, to resume normal spring growth (Weinberger 1967). This chilling, or rest requirement, is achieved during the relatively cool winter months. While some evidence suggests that winter rest can occur at temperatures as high as $12.8^{\circ} \mathrm{C}\left(55^{\circ} \mathrm{F}\right)$ for some peach varieties (Aron \& Gat 1991), most researchers have considered $7.2^{\circ} \mathrm{C}\left(45^{\circ} \mathrm{F}\right)$ as a critical threshold temperature for rest (Weinberger 1967, Sanders 1975, Scalabrelli \& Couvillon 1986). The required amount of chilling varies widely among peach varieties. While growers choose varieties based on some non-climatic factors, such as market season, shipping, and resistance to pests and diseases, they also must consider local winter temperatures. Two specific hazards influence their decisions: insufficient winter chilling and spring freeze. Insufficient chilling occurs when temperatures during the dormant season are anomalously high, inhibiting rest. Insufficient chilling disrupts spring growth, causing sporadic bud break and leaf development, and non-uniform fruit growth (Kish et al. 1973, Kish \& Purvis 1975, Ridley et al. 1986, Linvill et al. 1989). Freeze damage occurs when temperatures fall below $-2.2^{\circ} \mathrm{C}\left(28^{\circ} \mathrm{F}\right)$ after bud break, and is most likely during years when cold weather fulfills chilling requirements early in the winter season and anomalously warm late winter temperatures occur. Under these conditions the dormancy requirement is satisfied early, promoting premature spring growth and increasing the threat of frost losses

With regard to the aforementioned climatic hazards, the choice of appropriate peach varieties represents an adjustment to the opposing threats of spring freeze and insufficient chilling. Growers must choose varieties with chilling requirements high enough to avoid premature spring growth which increases the threat of spring freeze; but must not overcompensate by choosing varieties whose chilling requirements would not be met during most winter seasons. Under current climatic conditions, growers have achieved a balance between the 2 threats through experience, and with the help of agricultural experiment station studies reporting average temperature and consequent chilling at stations across the state (Kish et al. 1973, Kish \& Purvis 1975, Linvill et al 1989). Growers and researchers commonly use the concept of accumulated chilling hours, defined as the number of hours during the dormant season that are below a critical threshold temperature, to match peach varieties to typical climatic conditions.

Over 50 different peach varieties are grown in South Carolina. There are 3 general peach growing regions in the state: the Upper State, Ridge, and Coastal Plains (Fig. 1). Table 1 lists the top 10 varieties grown in each region with their associated chilling hour requirements, and the weighted mean chilling hour requirement for all varieties (Ridley et al. 1986, South Carolina Agricultural Statistics Service 1991). This survey shows that, even within relatively small regions, peach varieties have a wide range of required chilling hours. However, because average winter temperatures in the Upper State region are cooler (Fig. 2), varieties with higher chilling hour requirements tend to be located there. This insures that chilling requirements will not be satisfied prematurely, leaving peaches vulnerable to spring frost damage.

\section{METHODS}

Growers protect themselves against the threat of insufficient chilling by selecting varieties whose chilling hour requirements provide a buffer against interannual climatic variability. It is unclear whether this buffer is sufficient against the threat of increased winter temperatures. To test this, we calculated 1961-1990 average chilling hour accumulation, and contrasted it with chilling hour accumulation derived from 2 scenarios of winter-time warming. We con-

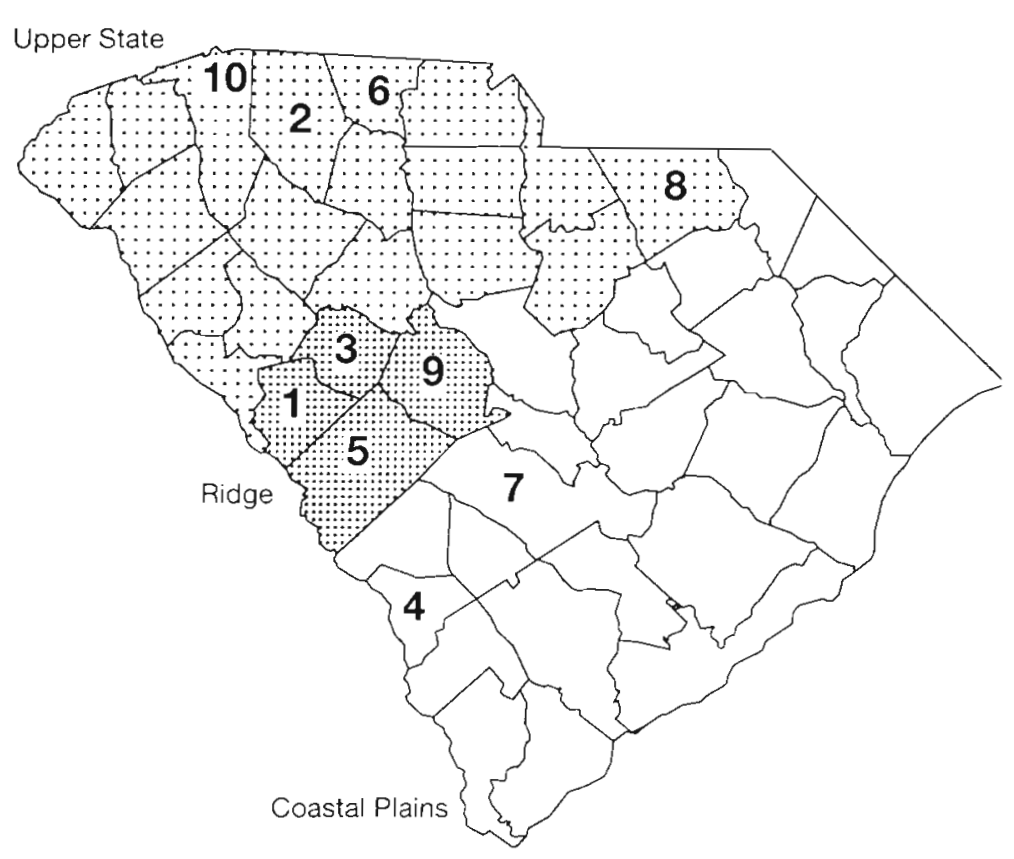

Fig. 1 South Carolina (USA) peach growing regions and the 10 most productive counties 
Table 1 Predominant peach varieties in South Carolina and their chilling hour requirements

\begin{tabular}{|c|c|c|}
\hline Varjety & $\%$ & $\begin{array}{l}\text { Chilling hour } \\
\text { requirement }\end{array}$ \\
\hline \multicolumn{3}{|l|}{ Upper state } \\
\hline Redglobe & 10.8 & $850-950$ \\
\hline Blake & 8.3 & 850 \\
\hline Redhaven & 7.8 & 950 \\
\hline Rio-Oso-Gold & 4.4 & 900 \\
\hline Monroe & 4.1 & 850 \\
\hline O'henry & 3.5 & 750 \\
\hline Jerseyqueen & 3.2 & 850 \\
\hline Loring & 3.2 & $750-950$ \\
\hline Tyler & 3.0 & 950 \\
\hline Coronet & 2.6 & $700-900$ \\
\hline \multicolumn{2}{|c|}{ Weighted mean chilling hour requirement: } & 865.2 \\
\hline \multicolumn{3}{|l|}{ Ridge } \\
\hline Harvester & 8.9 & 750 \\
\hline Redglobe & 7.7 & $850-950$ \\
\hline Redhaven & 6.2 & 950 \\
\hline Coronet & 6.0 & $700-900$ \\
\hline Jefferson & 5.4 & 850 \\
\hline Blake & 4.6 & 850 \\
\hline Cresthaven & 3.7 & 850 \\
\hline Loring & 3.2 & $750-950$ \\
\hline Springcrest & 2.9 & 650 \\
\hline June Gold & 2.5 & 650 \\
\hline \multicolumn{2}{|c|}{ Weighted mean chillıng hour requirement: } & 835.4 \\
\hline \multicolumn{3}{|l|}{ Coastal plain } \\
\hline June Gold & 14.0 & 650 \\
\hline Florida King & 13.7 & 450 \\
\hline Harvester & 12.5 & 750 \\
\hline Redglobe & 7.4 & $850-950$ \\
\hline Cary Mac & 6.6 & 750 \\
\hline Windblo & 6.0 & 800 \\
\hline Monroe & 3.4 & 850 \\
\hline Coronet & 3.2 & $700-900$ \\
\hline Jefferson & 3.0 & 850 \\
\hline Cresthaven & 2.0 & 850 \\
\hline \multicolumn{2}{|c|}{ Weighted mean chilling hour requirement: } & 782.1 \\
\hline
\end{tabular}

sidered 2 scenarios of climatic change for the purpose of assessing the hazards or benefits that warmer winter temperatures might pose to peach production if no adjustment occurred, or if adjustment occurred too slowly. In addition, we examined how winter temperature increases could change spring frost dates and potentially reduce this important hazard to peach growers.

\section{1-1990 average chilling hour accumulation}

We used maximum and minimum temperatures during the period 1961-1990 to calculate winter chilling hours under present climatic conditions. The chilling hour accumulation period extended from October 1

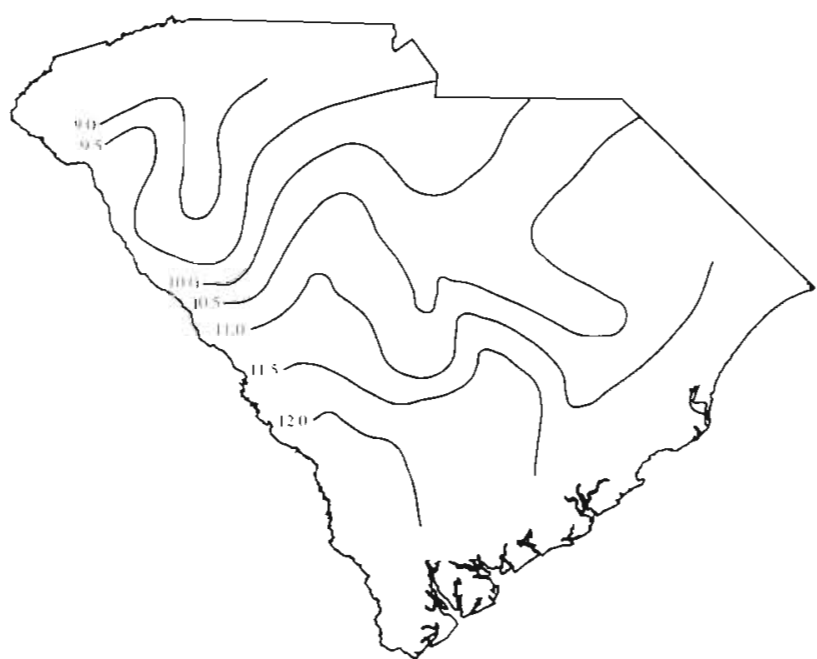

Fig. 2. Average chilling season (Oct 1 to Feb 28) temperature $\left({ }^{\circ} \mathrm{C}\right), 1961$ to 1990 normal

through February 28. Twenty-six stations were chosen according to the quality of their records during this period, and to achieve a state-wide distribution (Fig. 3).

Chilling hours were computed for each site and individual year using the common $7.2^{\circ} \mathrm{C}\left(45^{\circ} \mathrm{F}\right)$ threshold and a variation on the method developed by Linvill (1990). Hourly temperatures were computed from

$$
T(t)=\left(T_{\max }-T_{\min }\right) \times \sin \left[\frac{(\pi \times t)}{(D L+4)}\right]+T_{\min }
$$

where $T(t)=$ temperature at time $t$ hours after sunrise; $T_{\min }=$ daily minimum temperature $\left({ }^{\circ} \mathrm{F}\right) ; T_{\max }=$ daily maximum temperature $\left({ }^{\circ} \mathrm{F}\right) ; D L=$ daylength

Daytime chilling hours $(\mathrm{CH})$ were calculated by:

$$
C H=\left[\frac{(D L+4)}{\pi}\right] \times \arcsin \left[\frac{T_{c}-T_{\min }}{T_{\max }-T_{\min }}\right]
$$

where $T_{c}=$ threshold critical temperature $\left(45^{\circ} \mathrm{F}\right)$, and nighttime chilling hours $(\mathrm{CH})$ were calculated by:

$C H=(24-D L)-\exp \left[\frac{T_{\mathrm{s}}-T_{\mathrm{c}}}{T_{\mathrm{s}}-T_{\mathrm{min}}}\right] \times \ln (24-D L)$

where $T_{\mathrm{s}}$ is sunset temperature $\left({ }^{\circ} \mathrm{F}\right)$.

\section{Climatic change scenarios}

We considered 2 scenarios of climatic change in our analysis - average winter-time temperature increases of $2^{\circ} \mathrm{C}$ and $4{ }^{\circ} \mathrm{C}$. These values are based on winterseason temperature changes from equilibrium runs of the Goddard Institute for Space Studies (GISS), Geofluids Dynamics Lab (GFDL), and Oregon State University (OSU) GCMs (Hansen et al. 1984, Manabe 


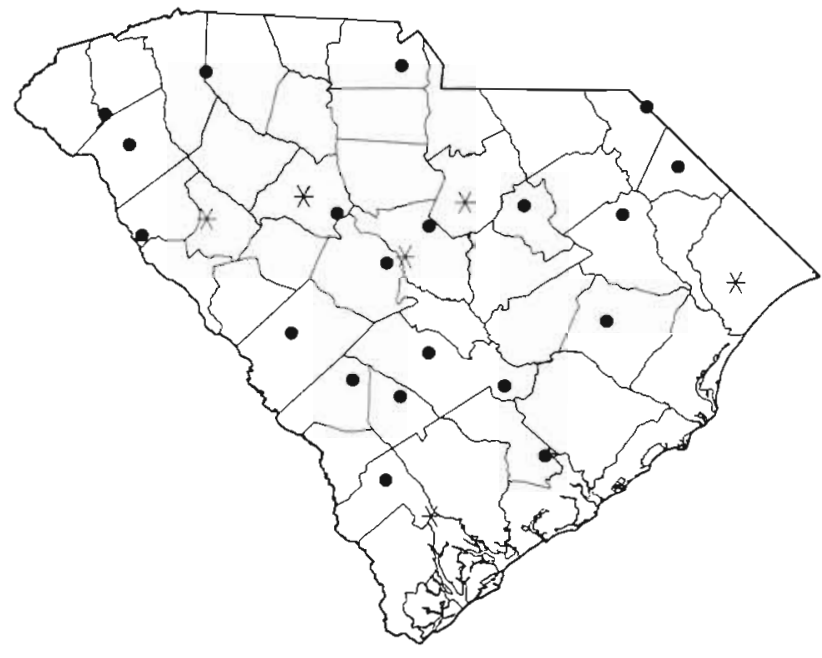

Fig. 3. Weather stations used in analysis. *: long-term 'century' stations

\& Wetherald 1987, Schlesinger \& Zhao 1989). The models showed $\mathrm{CO}_{2}$-induced temperature changes in the southeastern U.S. that ranged from 3.5 to $4.0^{\circ} \mathrm{C}$ (Smith \& Tirpak 1989).

Admittedly, there are some drawbacks to using GCM results at the regional scale. GCMs are global models and the accuracy of regional scenarios presently is not guaranteed by modelers (Mitchell et al. 1990). In addition, the temporal and spatial resolution of GCM output is quite coarse. However, GCMs remain our best tool for estimating potential climatic change, and guidance from 3 different models presents a range of possible future scenarios. Furthermore, we used seasonal temperature projections, one of the more reliable elements of current climatic change projections, and, therefore, one appropriate for a climate impact study (Schneider 1984, Riebsame 1990).

We examined how higher mean winter temperature could change the vulnerability of peaches by comparing average chilling hour accumulation under present conditions to chilling hour accumulation under the 2 climate change scenarios. These scenarios were created by adjusting the daily time series of maximum and minimum temperatures for each station and each year from 1961 to 1990 . In the first scenario, daily maximum and daily minimum temperatures were both increased by $2^{\circ} \mathrm{C}$. In the second scenario, they were both increased by $4^{\circ} \mathrm{C}$. This method assumes that winter season warming would be expressed as an equal change in maximum and minimum temperatures and does not consider potential changes in climatic variability and extreme temperatures.

It is likely that disproportionate changes in maximum or minimum temperature would affect chilling hour accumulation. As a test of the sensitivity of chilling hour accumulation to the nature of climatic change, we altered 139 yearly time series from 2 longterm stations (Yemassee and Newberry) and recalculated chilling hours under 3 different scenarios. A $2{ }^{\circ} \mathrm{C}$ temperature increase was expressed as: (A) a $4{ }^{\circ} \mathrm{C}$ increase in minimum temperature with no change in maximum temperature; (B) a $4{ }^{\circ} \mathrm{C}$ increase in maximum temperature with no change in minimum temperature; and (C) a $2{ }^{\circ} \mathrm{C}$ increase in both minimum and maximum temperatures. Our results show that changes in minimum temperature most dramatically decrease chilling hour accumulation (Table 2). This result is significant in the context of previous research showing greater increases in minimum temperatures than maximum temperatures during the past century (Karl et al. 1984, Folland et al. 1990, Idso \& Balling 1992) and GCM results suggesting similar expression of future climatic change (Mitchell et al. 1990).

Our decision to consider equal changes in maximum and minimum temperature results from uncertainties about future diurnal temperature changes, and analysis of the historical record from 6 long-term stations across the state (Fig. 3). In our analysis of the empirical record, we constructed an analog for warming at each station by examining pairs of years that had an average winter season temperature difference of $2^{\circ} \mathrm{C}$. We then calculated the difference in average winter season maximum and minimum temperatures between the 2 years in order to measure their relative contribution to the corresponding average temperature difference. Table 3 shows that the contribution of the maximum and minimum temperatures to average temperature differences is approximately the same when averaged over all possible pairs of years.

Table 2. Influence of various expressions of a $2{ }^{\circ} \mathrm{C}$ climatic change on chilling hour accumulation

\begin{tabular}{|ccccc|}
\hline Scenario & $\begin{array}{c}\text { Mean temperature } \\
\text { change }\left({ }^{\circ} \mathrm{C}\right)\end{array}$ & $\begin{array}{c}\text { Change to minimum } \\
\text { temperature }\left({ }^{\circ} \mathrm{C}\right)\end{array}$ & $\begin{array}{c}\text { Change to maximum } \\
\text { temperature }\left({ }^{\circ} \mathrm{C}\right)\end{array}$ & Mean chilling hours \\
\hline $\mathrm{A}$ & +2 & +4 & 0 & 908.7 \\
$\mathrm{~B}$ & +2 & 0 & +4 & 1135.8 \\
$\mathrm{C}$ & +2 & +2 & 0 & 1026.1 \\
$\mathrm{D}$ & None & 0 & 2 & 1334.9 \\
\hline
\end{tabular}


Table 3. Analog of a $2^{\circ} \mathrm{C}$ chilling season temperature difference, and relative contribution of maximum and minimum temperature

\begin{tabular}{|lcccc|}
\hline Station & $\begin{array}{c}\text { Average temperature } \\
\text { difference }\left({ }^{\circ} \mathrm{C}\right)\end{array}$ & $\begin{array}{c}\text { Maximum temperature } \\
\text { difference }\left({ }^{\circ} \mathrm{C}\right)\end{array}$ & $\begin{array}{c}\text { Minimum temperature } \\
\text { difference }\left({ }^{\circ} \mathrm{C}\right)\end{array}$ \\
\hline 381310 & +2 & 1.55 & 2.45 & $\mathrm{n}$ \\
381944 & +2 & 2.37 & 1.63 & 2.03 \\
381997 & +2 & 1.96 & 2.22 & 50 \\
383754 & +2 & 1.76 & 1.97 & 35 \\
386209 & +2 & 2.03 & 2.11 & 40 \\
389469 & +2 & 1.88 & 2.03 & 251 \\
Average & +2 & 1.96 & & 40 \\
\hline
\end{tabular}

While comparison of average chilling hour accumulation may measure the impact of mean winter temperature change, peach growers use stricter standards when choosing varieties. Therefore, we also calculated the number of chilling hours achieved $90 \%$ of the time under current conditions, and compared these values to those that would be achieved $90 \%$ of the time under the 2 scenarios of change. The $90 \%$ probability level was calculated using the mean, standard deviation, and $Z$-scores assuming a random Gaussian distribution of chilling hours (Kish \& Purvis 1975).

\section{Changes in frost dates}

It is possible that increasing winter temperatures would decrease the occurrence of frost and move the average date of the last spring frost earlier in the season. Assuming, as we are in our construction of new time series, that there is no accompanying change in climatic variability, and that the climatic change is expressed as equal changes in the maximum and minimum temperatures, the threat of damaging frosts could decrease. We examine this idea by comparing average last spring frost dates under current conditions to these average dates under our 2 scenarios of change. We use $-2.2{ }^{\circ} \mathrm{C}\left(28^{\circ} \mathrm{F}\right)$ as a threshold for a frost event.

\section{RESULTS}

Under current climatic conditions (1961 to 1990 normals) mean winter-season chilling hours range from 1050 to $1700 \mathrm{~h}$ across South Carolina (Fig. 4). These values exceed those required by peach varieties grown in the state by 600 to $750 \mathrm{~h}$. Since growers make variety choices using more conservative criteria, the distribution of the $90 \%$ probability of chilling hour accumulation provides more relevant information about the buffer against inter-annual variability that growers rely upon. These values range from 800 to $1550 \mathrm{~h}$
(Fig. 5), and exceed the chill hour requirements by 350 to $600 \mathrm{~h}$ in most parts of the state.

Under the $2^{\circ} \mathrm{C}$ warming scenario, mean chilling hour accumulation would drop substantially (Fig. 6). Average values would range from 775 on the southeastern Coastal Plain to $1350 \mathrm{~h}$ in the northwestern portion of the state. Despite the marked decrease, mean chill hours still exceed the requirements in most regions of the state. However, if growers use a $90 \%$ probability threshold, a $2{ }^{\circ} \mathrm{C}$ warming reduces chilling hour accumulation to a range between 525 to $1175 \mathrm{~h}$ (Fig. 7). These values are very close to the chilling hour requirement of peaches grown in many parts of the state.

The effect of a $4{ }^{\circ} \mathrm{C}$ warming is more drastic. Average chilling hour accumulation under this scenario drops below $550 \mathrm{~h}$ on the Coastal Plain and $1000 \mathrm{~h}$ in the northwest (Fig. 8). In nearly all parts of the state growers could expect average chilling hour accumulation to be at or below that required for normal spring growth. The $90 \%$ probability of chill hour accumulation under the $4{ }^{\circ} \mathrm{C}$ warming scenario ranges from 325 to $825 \mathrm{~h}$ (Fig. 9).

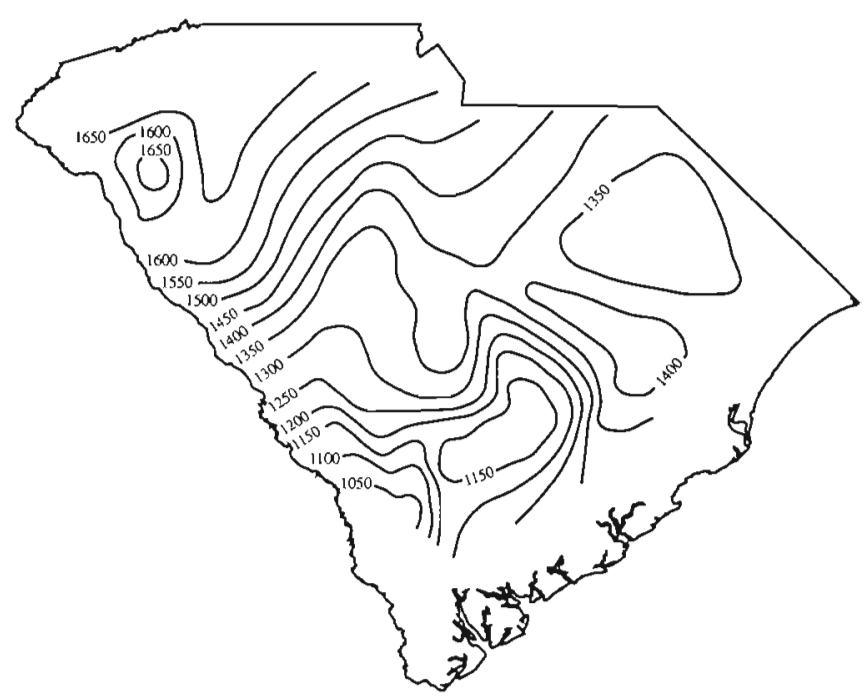

Fig. 4. Mean accumulated chilling hours, 1961 to 1990 normal 


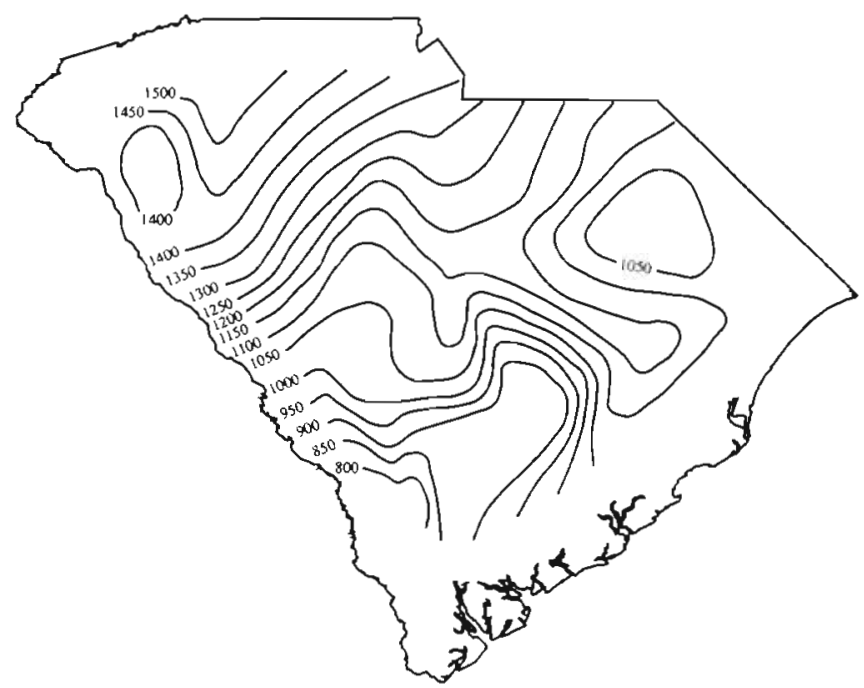

Fig. 5. Accumulated chilling hours achieved with $90 \%$ probability, 1961 to 1990 normal

Clearly, the warmed conditions would have a disastrous effect on the peach crop if growers did not choose varieties with lower chilling hour requirements.

Countering the increased threat of insufficient chilling is the possibility that killing frosts will not occur during the peach blossom season. Table 4 shows how the average date of the last spring frost changes under our 2 climate change scenarios. Under the 2 warming scenarios, the mean date $(50 \%$ probability) of the last spring frost and the $90 \%$ probability of the last spring frost occur considerably earlier. While the adjustment of these dates varies among different stations, a $2{ }^{\circ} \mathrm{C}$ warming generally moves the last frost date ahead by

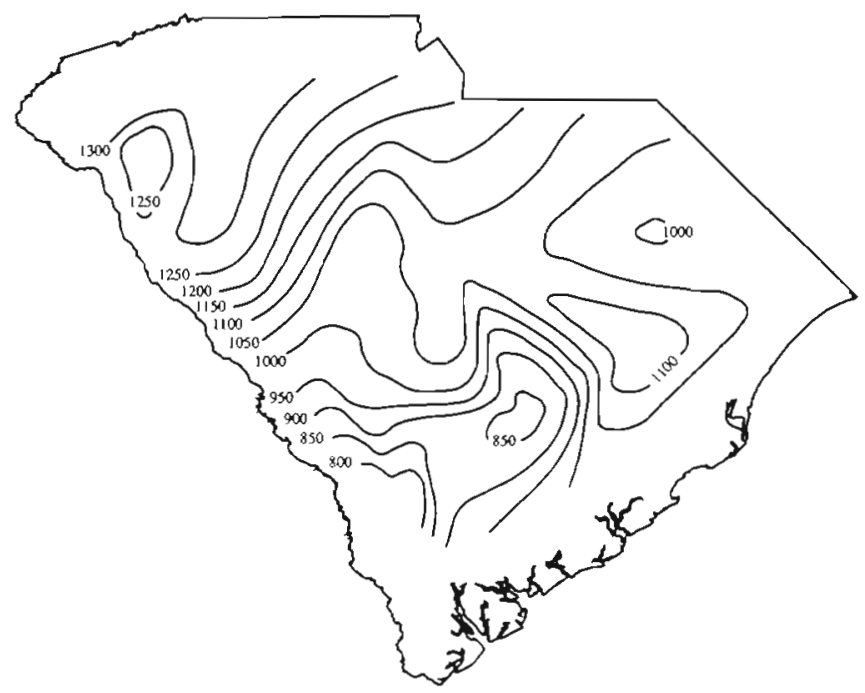

Fig. 6. Mean accumulated chilling hours under $2^{\circ} \mathrm{C}$ warming scenario

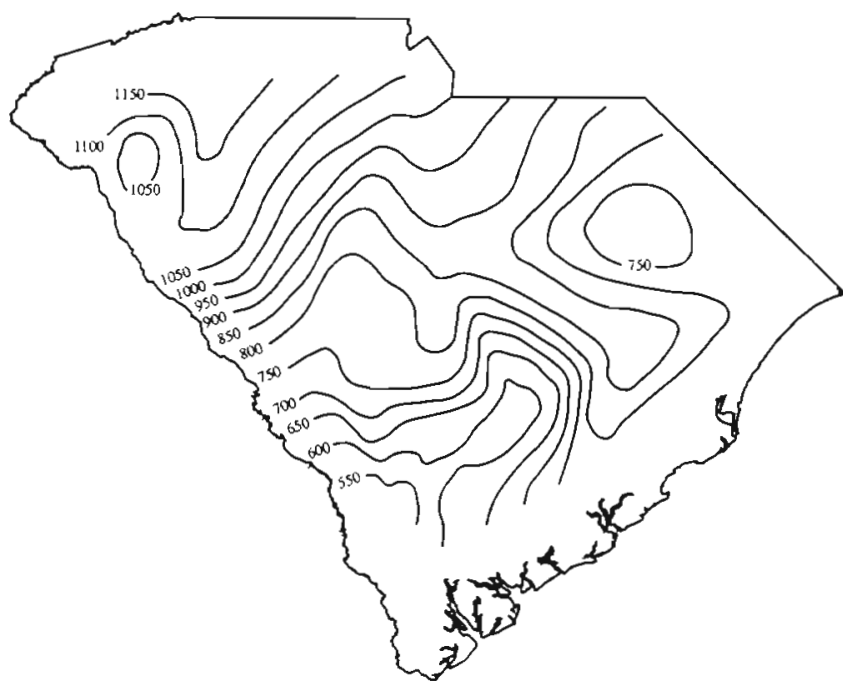

Fig. 7. Accumulated chilling hours achieved with $90 \%$ probability under $2{ }^{\circ} \mathrm{C}$ warming scenario

about $2 \mathrm{wk}$ and a $4^{\circ} \mathrm{C}$ warming moves the last frost date ahead by about $4 \mathrm{wk}$.

\section{DISCUSSION AND CONCLUSIONS}

The results reported above suggest that chilling hours during the winter season could decrease substantially under the warming scenarios provided by current GCMs. Considered alone, this decrease could cause delayed or abnormal spring growth. Growers have adapted their orchard practices to current climatic normals in order to buffer themselves against inter-annual

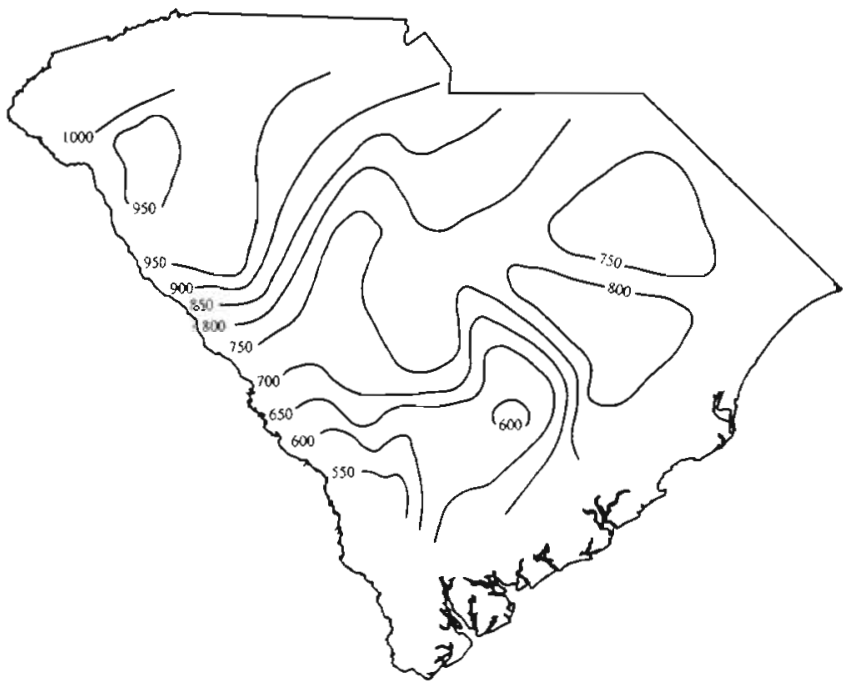

Fig. 8. Mean accumulated chilling hours under $4^{\circ} \mathrm{C}$ warming scenario 


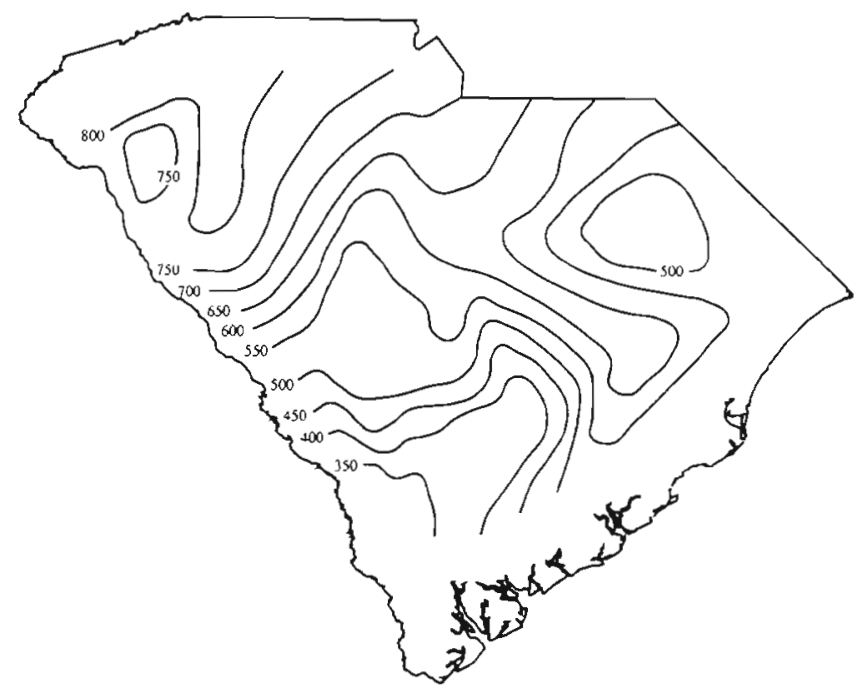

Fig. 9. Accumulated chilling hours achieved with $90 \%$ probability under $4^{\circ} \mathrm{C}$ warming scenario

variability. Our results show that this buffer would be eroded with a $2^{\circ} \mathrm{C}$ warming during the chilling season. Growers in certain portions of the state would experience greater frequency of insufficient chilling if cultivars with the same chilling requirements were used. A $4^{\circ} \mathrm{C}$ warming would significantly increase the probability of insufficient chilling and could affect growers across the entire state.
In order to put these results into an historical perspective, we examined the climatological record of 6 long-term South Carolina stations (Fig. 10). During the 20th century, 6 years had winter temperature anomalies greater than $+2^{\circ} \mathrm{C}(1932,1937,1949$, $1950,1957,1974)$. Chilling hour accumulation during these same years was at least $400 \mathrm{~h}$ below the 1961 to 1990 normal. While peach yields in each of these years was reduced, it is unclear whether insufficient chilling was solely to blame. In fact, several factors can cause reduced peach yields. What is clear, however, is that insufficient chilling of the degree proposed by our scenarios has been relatively infrequent. This could cause growers to be cautious about changing varieties based on scenarios of winter warming.

It is likely that such caution could also be driven by the current problem that frost poses for peach growers in the state. Frost has reduced peach yields during several years during the past decade, and is presently seen as growers' greatest hazard. Our results show that, without changes in climatic extremes, last spring frosts would occur earlier in the season. This could reduce the likelihood of killing frosts during the peach bloom and early fruit periods. The combination of fewer chilling hours and earlier last spring frosts could have a positive effect on peach production. Scalabrelli \& Couvillon (1986) have shown that reduced chilling significantly in-

Table 4. Last spring frost dates in South Carolina under current climatic conditions and climatic change scenarios

\begin{tabular}{|c|c|c|c|c|c|c|}
\hline \multirow[t]{2}{*}{ Station } & \multicolumn{3}{|c|}{ Mean frost date } & \multicolumn{3}{|c|}{$90 \%$ probability of last frost before date shown } \\
\hline & Current & $+2^{\circ} \mathrm{C}$ & $+4^{\circ} \mathrm{C}$ & Current & $+2^{\circ} \mathrm{C}$ & $+4^{\circ} \mathrm{C}$ \\
\hline Aiken & Mar 14 & Mar 4 & Feb 12 & Mar 30 & Mar 23 & Mar 7 \\
\hline Anderson & $\operatorname{Mar} 24$ & Mar 10 & Feb 24 & Apr 8 & $\operatorname{Mar} 26$ & Mar 10 \\
\hline Bamberg & Mar 10 & Feb 20 & Feb 4 & Mar 29 & Mar 12 & Feb 25 \\
\hline Bishopville & Mar 21 & Mar 2 & Feb 14 & Apr 9 & Mar 21 & Mar 8 \\
\hline Blackville & Mar 14 & Feb 18 & Feb 7 & Apr 1 & Mar 10 & Feb 25 \\
\hline Calhoun Falls & Mar 12 & Feb 28 & Feb 13 & Mar 31 & Mar 16 & Mar 4 \\
\hline Clemson & Mar 24 & Mar 7 & Feb 24 & Apr 13 & Mar 25 & Mar 13 \\
\hline Columbia & Mar 15 & Mar 1 & Feb 13 & Apr. 4 & Mar 21 & Mar 8 \\
\hline Conway & Mar 1 & Feb 13 & Feb 3 & Mar 23 & Mar 13 & Feb 25 \\
\hline Dillon & Mar 22 & Mar 1 & Feb 18 & Apr 9 & Mar 21 & Mar 12 \\
\hline Florence & Mar 10 & Feb 17 & Feb 5 & Mar 30 & $\operatorname{Mar} 16$ & Feb 26 \\
\hline Greer & Mar 24 & Mar 6 & Feb 23 & Apr 8 & Mar 25 & Mar 14 \\
\hline Greenwood & Mar 21 & Mar 10 & Feb 22 & Apr 9 & Apr 2 & Mar 12 \\
\hline Hampton & Mar 4 & Feb 16 & $\operatorname{Jan} 29$ & Mar 22 & Mar 6 & Feb 27 \\
\hline Holly Hill & Mar 11 & Feb 16 & $\operatorname{Jan} 31$ & Mar 30 & Mar 12 & Feb 18 \\
\hline Kingstree & Mar 16 & Feb 20 & Feb 13 & Apr 9 & Mar 16 & Mar 7 \\
\hline Little Mountain & Mar 18 & Mar 1 & Feb 14 & Apr 7 & Mar 19 & Mar 12 \\
\hline McColl & Mar 17 & Mar 2 & Feb 10 & Apr 7 & Mar 23 & Mar 11 \\
\hline Newberry & Mar 22 & Mar 6 & Feb 18 & Apr 6 & Mar 24 & Mar 11 \\
\hline Orangeburg & Mar 12 & Feb 15 & Feb 3 & Apr 2 & Mar 3 & Feb 26 \\
\hline Sandhill Exp Station & Mar 17 & Feb 24 & Feb 8 & Apr 5 & Mar 11 & Feb 25 \\
\hline Summerville & Mar 11 & Feb 20 & Feb 5 & Apr 5 & Mar 11 & Feb 25 \\
\hline Winthrop College & Mar 16 & $\operatorname{Mar} 2$ & Feb 17 & Apr 5 & Mar 22 & Mar 11 \\
\hline Yemassee & Mar 8 & Feb 16 & Feb 11 & Mar 31 & Mar 8 & Mar 3 \\
\hline
\end{tabular}




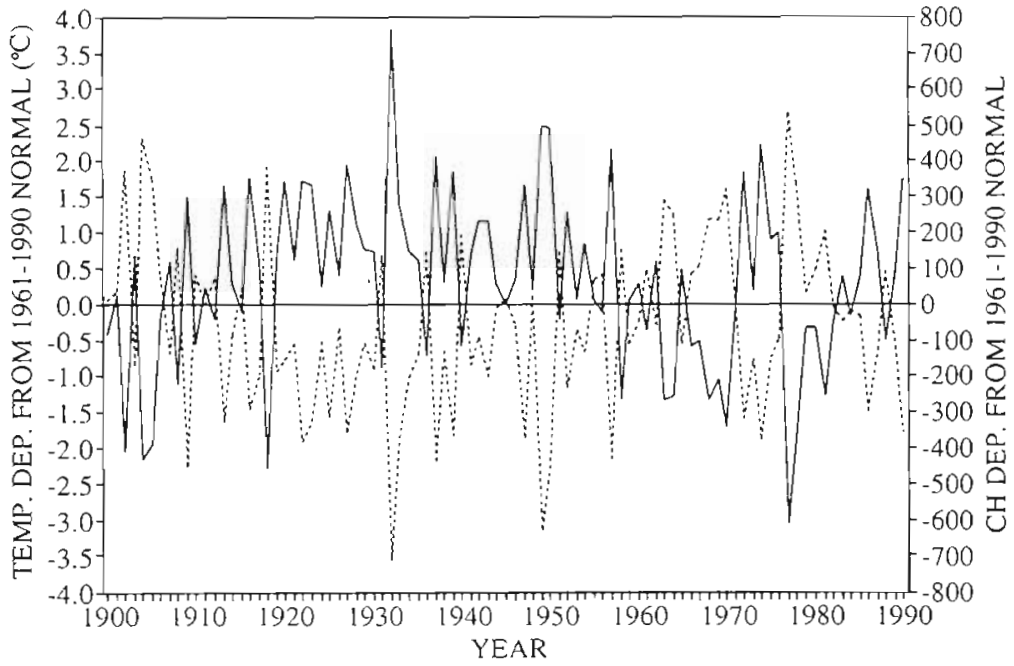

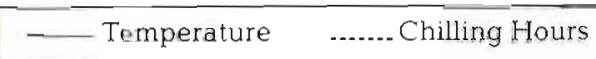

Fig. 10. Annual chilling season temperature and chilling hour departure from 1961 to 1990 mean for 6 long-term stations creases the growing degree hour $\left(\mathrm{GDH}^{\circ} \mathrm{C}\right)$ requirement for budbreak in 'Redhaven' peaches. Therefore, warmer winter conditions would not necessarily accelerate the process of budbreak and fruit set during the spring. Delayed budbreak would protect peaches from killing spring frosts that would occur earlier in the season.

Our results provide a preliminary investigation into the possible impacts of climatic change on peach production. Several issues remain unanswered, and are restricted by our present knowledge of the nature of future climatic change and variability and the link between seasonal peach growth and environmental conditions. Our analysis does not include the possibility of changes in climatic variability and, particularly, changes in extreme events because of present uncertainties of future climate. We also do not address questions about how rapidly climatic change could occur. Very gradual changes (e.g. $2^{\circ} \mathrm{C}$ over $100 \mathrm{yr}$ ) possibly would allow growers an opportunity to adjust to new climatic conditions. Further investigation in this area would involve an analysis of how growers presently make adjustments. Additionally, work directed towards the development of a broadly applicable model for predicting bloom dates would help researchers to understand the competing challenges of insufficient chilling and adjusted frost dates. Finally, our analysis could be extended to include the impacts of winter temperature increases on other fruit species and regions in the southeastern United States. We have found through a preliminary examination of selected stations from the U.S. Historical Climate Network (HCN; Hughes et al. 1992) that $2^{\circ} \mathrm{C}$ and $4^{\circ} \mathrm{C}$ warming scenarios could change chilling hours and frost dates across the Southeast in a manner similar to that in South Carolina.
Acknowledgements. The authors thank Karen Beidel, Michael Burdett, Jonathan Byron, Rex Cammack, Don Campbell, Yang Cheng, Dale Linvill, Brooks Tomlin, and John Winberry for their editorial comments and technical assistance in preparing this manuscript. Partial funding for this project came from the Southeast Regional Climate Center

\section{LITERATURE CITED}

Adams, R. M., Rosenzweig, C., Peart, R. M., Ritchie, J. T., McCarl, B. A., Glyer, J. D., Curry, R. B., Jones, J. W., Boote, K. J., Allen, L. H. (1990). Global climate change and U.S. agriculture. Nature 345: 219-224

Aron, R, Gat, Z. (1991). Estimating chilling duration from daily temperature extremes and elevation in Israel. Clim. Res. 1: $125-132$

Beukema, J. J., Wolff, W. J., Brouns, W. M. (eds.) (1990). Expected effects of climatic change on marine coastal ecosystems. Kluewer Academic, Boston

Cooter, E. J. (1990). The impact of climate change on continuous corn production in the southern U.S.A. Clim. Change 16: 53-82

Eid, E. M., Hulsbergen, C. H. (1991). In: Jäger, J., Ferguson, H. L. (eds.) Climate change: science, impacts and policy Proceedings of the second world climate conference. Cambridge University Press. New York, p. 301-309

Folland, C. K., Karl, T R., Vinnikov, K. Ya. (1990). Observed climate variations and change. In: Houghton, $J$. I., Jenkins, G. J., Ephraums, J. J (eds.) Climate change: the IPCC scientific assessment. Cambridge University Press, New York, p. 199-238

Hansen, J., Lacis, A., Rind, D., Russell, G., Stone, P., Fung, I. Ruedy, R., Lerner, J. (1984). Climate sensitivity: analysis of feedback mechanisms. In: Hansen, J. E., Takahashi, T (eds.) Climate processes and climate sensitivity. American Geophysical Union, Washington, DC, p. 130-163

Hansen, J., Fung, I., Lacis, A., Rind, D., Lebedeff, S., Ruedy, R., Russell, R. (1988). Global climate changes as forecast by Goddard Institute for Space Studies' three-dimensional model. J. geophys. Res. 93: 9341-9364

Hansen, J., Lebedeff, S. (1988). Global surface air temperatures: update through 1987 Geophys. Res. Lett. 15. $323-326$ 
Hughes, P. Y., Mason, E. H., Karl, T R., Brower, W. A. (1992) United States Historical Climatology Network of daily temperature and precipitation data. ORNL/CDIAC-50, NDP-042. Carbon Dioxide Information Analysis Center Oak Ridge National Lab, Oak Ridge, TN

Idso, S. B., Balling, R. C. Jr (1992). US temperature/precipitation relationships: implications for future 'greenhouse' climates. Agric. For. Meteor. 58(1-2): 143-147

Jäger, J., Ferguson, H. L. (1991). Climate change: science, impacts and policy. Proceedings of the second world climate conference. Cambridge University Press, New York

Karl, T R., Kukla, G., Gavin, J. (1984). Decreasing diurnal temperature range in the United States and Canada from 1941-1980. J. Clim. appl. Met. 23: 1489-1504

Katz, R. W. (1988). Statistics of climate change: implications for scenario development. In: Glantz, M. H. (ed.) Societal response to regional climate change. Westview Press, Boulder, CO, p. 95-112

Kish, A. J., Purvis, J. C. (1975). Winter and spring temperature hazards to South Carolina peaches. South Carolina Agr. Wea. Res. Ser. No. 46

Kish, A. J., Purvis, J. C., Ferree, R. J (1973). Probability of peach tree dormancy during the winter in South Carolina. South Carolina Agr. Wea. Res. Ser. No. 36

Lindzen, R. S. (1990). Some remarks on global warming Environ. Sci. Technol. 24: 424-426

Linvill, D. E. (1990). Calculating chilling hours and chill units from daily maximum and minimum temperature observations. Hortic Sci. 25: 14-16

Linvill, D. E., Smith, D. J., Pardue, J. S. (1989). Chilling hours and chill units for South Carolina. Clemson University Cooperative Extension Service, Circular 651, Clemson, SC

Manabe, S., Wetherald, R. (1987). Large-scale changes of soil wetness induced by an increase in atmospheric carbon dioxide. J. Atmos. Sci. 44: 1211-1236

Mitchell, J. R. B., Manabe, S., Meleshko, V., Tokioka, T (1990). Equilibrium climate change - and its implications for the future. In: Houghton, J. T, Jenkins, G. J., Ephraums, J. J. (eds.) Climate change: the IPCC scientific assessment. Cambridge University Press, New York. p. $133-164$

National Academy of Sciences (1991). Policy implications of greenhouse warming - synthesis panel committee on science, engineering, and public policy. National Academy Press, Washington, DC

Parry, M. L., Carter, T R. (1985). The effect of climatic variations on agricultural risk. Clim. Change 7: 95-110

Peart, R. M., Jones, J. W., Curry, R. B., Boote, K., Allen, L. H Jr (1989). Impact of climate change on crop yield in the southeastern U.S.A. In: Smith, J. B., Tirpak, D. A. (eds.) The potential effects of global climate change on the

Editor: V. Meentemeyer
United States. U.S. Dept of Agr., Agricultural Research Service, Washington, DC, Appendix C-1, 2-1 to 2-54

Ridley, J. D., Cain, D. W., Newall, W. C. (1986). Evaluation of selected peach cultivars for South Carolina. Clemson University Cooperative Extension Service, Circular 574 Clemson, SC

Riebsame, W. E. (1990). Anthropogenic climate change and a new paradigm of natural resource planning. Prof. Geogr. 42(1): $1-12$

Ritchie, J T., Baer, B. D., Chou, T Y. (1989). Effect of global climate change on agriculture: Great Lakes region. In Smith, J. B., Tirpak, D. A. (eds.) The potential effects of global climate change on the United States. U.S. Dept of Agr., Agricultural Research Service, Washington, DC Appendix C-1, 1-1 to 1-30

Rosenzweig, C. (1990). Crop response to climate change in the southern Great Plains: a simulation study. Prof. Geogr 42(1): $20-37$

Sanders, C. G. (1975). Climatic chilling in Georgia. Georgia Agric. Res. 18: 19-22

Scalabrelli, G., Couvillon, G. A. (1986). The effect of temperature and bud type on rest completion and the $\mathrm{GDH}{ }^{\circ} \mathrm{C}$ requirement for budbreak in 'Redhaven' peach. J. Am. Soc. Hort. Sci. 111(4): $537-540$

Schlesinger, M., Zhao, Z. C. (1989). Seasonal climatic changes induced by doubled $\mathrm{CO}_{2}$ as simulated by the OSU atmospheric GCM/mixed layer ocean model. J. Clim. 2: 459-495

Schneider, S. H. (1984). On the empirical verification of model-predicted $\mathrm{CO}_{2}$-induced climatic effects. In: Hansen, J. E., Takahashi, T. (eds.) Climatic processes and climate sensitivity. American Geophysical Union, Washington, DC, p. 187-201

Smith, J B., Tirpak, D. A. (eds.) (1989). The potential effects of global climate change on the United States. U.S. EPA Washington, DC

South Carolina Agricuitural Statistics Service (1991). South Carolina fruit tree survey, 1991. Agricultural Extension Circular 471, South Carolina Agricultural Statistics Service, Columbia

Waggoner, P. E. (ed.) (1990). Climate change and U.S. water resources. Wiley, New York

Washington, W. M., Meehl, G. A. (1989). Climate sensitivity due to increased $\mathrm{CO}_{2}$ : experiments with a coupled atmosphere and ocean general circulation model. Clim. Dyn. 4: 1-38

Weinberger, J. H. (1967). Some temperature relations in natural breaking of the rest of peach flower buds in the San Joaquin Valley, California. J. Proc. Am. Hort. Soc. 91: 84-89

Wilson, C. A., Mitchell, J. F. B. (1987). A doubled $\mathrm{CO}_{2}$ climate sensitivity experiment with a GCM including a simple ocean. J. geophys. Res. 92 (D11): 13315-13343

Manuscript first received: August 18, 1992

Revised version accepted: May 26, 1993 